\title{
ASSESSMENT AND REMOVAL OF SUSPENDED SOLIDS IN HOSPITAL WASTEWATER USING CLAY IN SRI LANKA
}

\author{
SANSFICA M. YOUNG ${ }^{1}$, A.M.I.U. KUMARA ${ }^{2}$, K.G.R.D.H. KATTANGE ${ }^{2}$, \\ T.H.N.G. AMARAWEERA ${ }^{2}$, Y.M.S.S. YAPA ${ }^{3}$ \\ ${ }^{1}$ Department of Environmental Technology, University of Colombo, Sri Lanka \\ ${ }^{2}$ Department of Applied Earth Sciences, Uva Wellassa University, Sri Lanka \\ ${ }^{3}$ Postgraduate Institute of Medicine, University of Colombo, Sri Lanka
}

Corresponding authore-mail: sansfica@et.cmb.ac.lk

(Received: $2^{\text {nd }}$ December 2020; Accepted: $7^{\text {th }}$ March 2021)

\begin{abstract}
Direct discharge of untreated hospital wastewater (HWW) can create severe environmental impacts. Hence, the study focuses on assessing the performance of an existing treatment plant, while determining the most suitable filter material from five different alluvial clays to remove total suspended solids (TSS) and total dissolved solids (TSS) in HWW and investigate a hospital that does not have a treatment plant to elaborate the requirement of a treatment plant. Wastewaters from Provincial General Hospital (PGH, n=5) and Base Hospital (BHTB, n=4) were collected weekly over three weeks (total $n=27$ ) where physical $(n=4)$, chemical $(n=12)$ and biological $(n=1)$ parameters were measured. The clays were treated with HWW, and the adsorption of TSS and TDS to clay was determined. The water quality after the trickling filter in PGH shows a clear drop for $\mathrm{BOD}_{5}$, TSS, and $\mathrm{pH}$. Maximum values for $\mathrm{BOD}_{5}, \mathrm{COD}$, TSS, and $\mathrm{PO}_{4}{ }^{3-}$ of the waters were 108, 290, 904, and $16.39 \mathrm{mg} / \mathrm{L}$, respectively, and are much higher than the National Environmental Act (CEA) standards. In BHTB, all discharged water outlets are open to the environment, and the $\mathrm{BOD}_{5}, \mathrm{PO}_{4}{ }^{3-}$ and $\mathrm{NO}_{3}{ }^{-}$of discharged water varies within $8-98,3.77-8.16$, and $0.80-14.60 \mathrm{mg} / \mathrm{L}$ and are higher than CEA standards. The treatment plant at PGH is unsatisfactory to meet the increasing capacity requirements, thus needs improvements, and a treatment plant is required for BHTB. The highest removal of TSS was achieved using illite clay within two weeks, and the removal percentage is $96 \%$ while it was showing removal of Benzidine dihydrochloride $\left(\mathrm{C}_{12} \mathrm{H}_{12} \mathrm{~N}_{2} .2 \mathrm{HCl}\right)$, Neodymium titanium oxide $\left(\mathrm{Nd}_{2} \mathrm{Ti}_{2} \mathrm{O}_{7}\right)$, Bismuth selenide $\left(\mathrm{Bi}_{2} \mathrm{Se}_{3}\right)$ and Iron fluoride $\left(\mathrm{FeF}_{3}\right)$ which are found to be in $\mathrm{HWW}$.
\end{abstract}

Keywords: Hospital, Wastewater, Treatment, Environment, Clay

\section{INTRODUCTION}

Due to the growth in medical services and products during the recent decades, the generation of hospital wastewater (HWW) has been increasing and HWW is of great concern due to its detrimental effects on the environment because of the direct discharge to the natural water bodies (Mahmoudkhani et al., 2012; Meo et al., 2014; Carraro et al., 2016).
Hospital wastewater may include wastewaters from medical tests, blood, urine, feces, gastric fluids, and other body liquids, disinfectants, solvents, acids, bases, reagents, metals, blackwater which includes non-metabolized pharmaceuticals, micro-organisms, and any other medical waste discarded by the hospital (Emmanuel et al., 2002; Jones et al., 2005; 
Carraro et al., 2016; Pandey and Dwivedi, 2016).

Prior studies show that there are some deficiencies in existing primary treatment plants which are not able to treat HWW unto an optimum standard and it treats wastewater by leaving major contaminants such as pharmaceuticals (Nemathaga et al., 2008; Prayitno et al., 2013; Frederic and Yves, 2014; Tilley et al., 2014; Chanpika et al., 2015; Todt, 2015; Wiest et al., 2018). Moreover, direct discharge of HWW without any treatment is common practice in the developing world including some hospitals in Sri Lanka (Haniffa, 2004; Kumarathilaka et al., 2015). If HWW is left untreated, it may lead to outbreaks of communicable diseases as well as other severe environmental pollution which contributes to increased oxygen demand and nutrient, pharmaceutical loading of water bodies which may result in the promotion of growth of toxic algal blooms, tropical unbalance, destabilized aquatic ecosystem, increasing Viral and Bacterial concentrations which may have acute toxicity (Emmanuel et al., 2002; Aththanyaka et al., 2014) and bioaccumulation of pharmaceuticals in ecosystems (Jean et al., 2012; Zenker et al., 2014; Carraro et al., 2016; Paulus et al., 2019).

However, it has been reported that higher levels of suspended solids in the water body can often mean higher concentrations of bacteria, nutrients and heavy metals. In the wastewater which may attach to sediment particles. Even studies have shown that higher levels of suspended solids create hindrances to the proper function of treatment plants (Kumarathilaka et al., 2015). Clay can be used as a coagulant to remove solids in wastewater (Jiang et al., 2004; Hascakir and Deniz, 2008) but available studies specifically on clay as an adsorbent in removing solids in HWW is limited.

Clays are beneficial and successful materials that have been used for the purification of water mainly as an adsorbent to remove contaminants. Clays and their modified composites are either better or equivalent in contaminant adsorption capacity from water (Srinivasan, 2011). Large specific surface area, chemical and mechanical stability, layered structure, high cation exchange capacity (CEC) has made the clays excellent adsorbent materials (Cadena et al., 1990). Thus, clays can be used as a natural adsorbent which also is of low cost.

\section{STUDY AREA}

\section{Provincial General Hospital}

Provincial General Hospital (PGH), is the largest hospital in Uva Province which consists of a staff of 2,000 and the hospital has nearly 1,453 beds. Apart from that, the hospital consists of 22 medical/surgical departments, 4 operation theaters, 5 diagnostic departments, 4 patient departments, 10 clinical services, 5 emergency care units and 10 other supportive services. It was reported that wastewater production of the hospital exceeds the capacity of $200 \mathrm{~m}^{3} /$ day that of the existing treatment plant consisting of trickling filtration system.

Here, the common sump is with a capacity of 20 $\mathrm{m}^{3}$ and it collects water including septic wastage, laboratory waste, kitchen waste, waters from clinical units and wards throughout 24 hours of the day. Then, water is pumped into two settling tanks with each having a capacity of $114 \mathrm{~m}^{3}$ and 6 hours retention time. After that, water is filtered by two trickling filters having a capacity of $285 \mathrm{~m}^{3}$ each $(15 \mathrm{~m}$ diameter and 1.5 $\mathrm{m}$ depth) and filter material are $\sim 12 \mathrm{~cm}$ average diameter rock (Hornblende-biotite gneiss) partials. Then water is collected by two secondary settling tanks with the capacity of 114 $\mathrm{m}^{3}$ each and with a retention time of 6 hours. Finally, water moves through a UV treatment plant with a thickness of $15 \mathrm{~cm}$ water layer. The target dose is $70.0 \mathrm{~mJ} / \mathrm{cm}^{2}$, and a flow rate of 40 $\mathrm{m}^{3} /$ hour with UV transmittance of $95 \%$. After the UV treatment plant, water is discharged to the environment. 


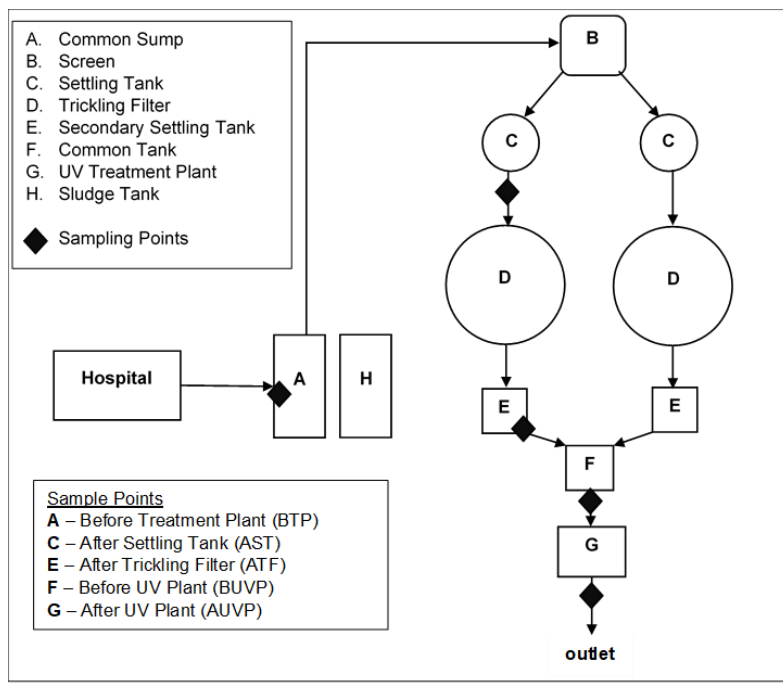

Fig. 1. The sampling points of the trickling filtration system in Provincial General Hospital

In this study, water samples were collected from five points of the treatment plant (Fig.1). Provincial General Hospital carried out a color code system in their waste management and the hospital sorts out the different types waste materials according to a color code. The hospital does not mix solid clinical materials such as syringes, cotton wool and plasters, and radioactive elements generated in medical units with wastewater. Excluding those components, wastewater is mixed with; blackwater, wash water from clinical units and wards, laboratory waste, greywaters discharged from kitchen, administration and other places. Heavy growth of algae was observed in the treatment plant and water emits an unpleasant odor.

\section{Base Hospital - Type B}

Base Hospital - Type B (BHTB), is smaller than PGH. It consists of 235 staff members and 215 beds. Nearly, 1,000 people obtain service from the hospital daily. However, there is no treatment facility for treating water in the hospital. In the study, there are four main sampling points which were identified as wastewater outlets including laboratory outlet where all the laboratory waste comes out, common water outlet where waste from wards and washrooms comes out, tap near the kitchen where wash water from the tap comes out and
RO Plant Effluent Outlet where wasted effluent of RO plant comes out (Fig. 2).

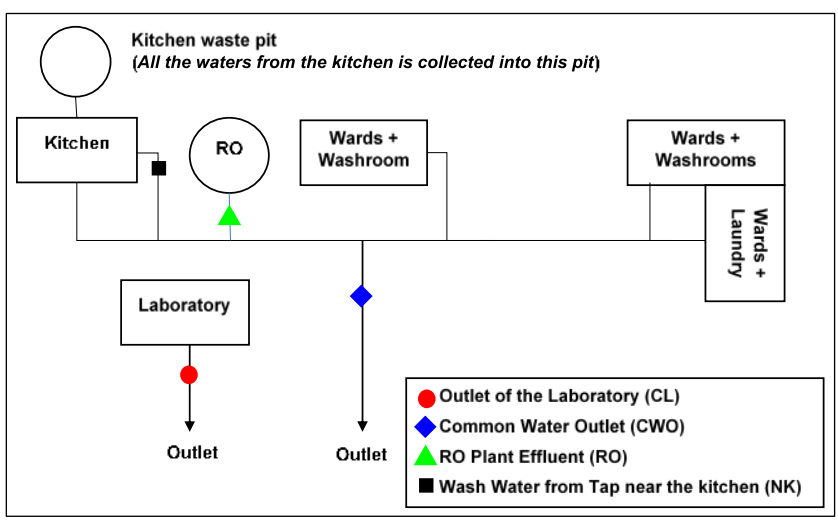

Fig. 2. Main wastewater outlets in Base HospitalType $B$ and the sampling points

Therefore, this research focused to (a) identify the effectiveness and performance in an existing treatment plant in a Provincial General Hospital (PGH) (b) look into the requirement of a treatment plant for BHTB where HWW is discharged into the environment without any treatment and (c) determine the most suitable filter material from five different alluvial clay deposits in Sri Lanka to remove total suspended solids (TSS) and total dissolved solids (TDS) in HWW.

\section{MATERIALS AND METHODS}

The experimental setup was developed to measure the HWW quality parameters in two different types of hospitals, to examine the treatment performance of the treatment plant in treating HWW and to analyze the effect of clay solids in solids removal of HWW.

\section{Sample Collection in Hospitals}

Samples were collected for three weeks, weekly in both the PGH and BHTB. Cleaned $500 \mathrm{~mL}$ Polyethylene terephthalate (PET) bottles were used and grab sampling method was used for the sample collection. Sampling points of PGH were selected through the treatment plant and they were; common sump (before treatment plant - 
BTP), after the settling tank (AST), after the trickling filter (ATF), before the UV plant (BUVP) and after the UV plant (AUVP) (Fig. $1)$.

There were 4 places that were identified as main wastewater outlets in BHTB; common water outlet (CWO) which delivers waters from wards and laundry, laboratory water outlet (CL) which delivers water from the laboratory in the hospital, effluent water outlet of RO filter (RO) in the hospital and tap near the kitchen (NK), and water samples were collected by grab sampling method from these places (Fig. 2).

\section{Water Quality Parameter Analysis}

Wastewater quality was measured through physical parameters; temperature $(\mathrm{pH}$ probeHoriba D50 series) and electrical conductivity (EC) (EC Probe-Horiba D50 series) were measured soon after the sample was collected, and total suspended solids (TSS), total solids was measured (Membrane filtration method) at the laboratory.

As chemical parameters; $\mathrm{pH}$ ( $\mathrm{pH}$ probe-Horiba D50 series), oxidation reduction potential (ORP) (ORP probe-Horiba D50 series) and dissolve oxygen (DO) (DO probe - Horiba OM-14) was measured soon after the sample collection and five-day biochemical oxygen demand $\left(\mathrm{BOD}_{5}\right)$ (Winkler method), chemical oxygen demand (COD) (Closed Reflux, Titrimetric method), Nitrate (Ultraviolet Spectrophotometric Screening method measured in visible range $540 \mathrm{~nm}$ ), Phosphate (Ascorbic acid method), total dissolved solids (TDS), TDS MeterEUTECH Instruments - CON 510), Fe, Mn, Cd and $\mathrm{Cu}$ (Atomic absorption spectrometer AA240 - VARIAN), and as biological parameters faecal coliform was measured at the laboratory (APHA. 1998).

\section{Calculation for Data Normalization}

The water quality parameters for two hospitals were checked whether they meet CEA accepted discharge standards of Sri Lanka (National Environmental (Protection and Quality) Regulations, No. 1 of 2008) while the parameter of dissolved oxygen (DO) is checked with the maximum tolerance limit (MTL) mentioned in Begum and Harikrishna (2008). Then, the normalization of data was done by using the equation,

$$
\mathrm{n}=\frac{\text { Value of the Quality Parameter }}{\text { CEA Accepted Standard }}
$$

Where the obtained value for ' $n$ ' will indicate that the tested parameters, $n>1$ as enriched and $\mathrm{n}<1$ depleted for the disposal of effluents. According to the obtained $n$ values, 3 graphs were created with respect to the particular water quality parameters for 3 days (Figs. 3 and 4).

\section{Clay Analysis}

To determine the TSS and TDS removal using clay, HWW samples were collected from the location before the UV plant (BUVP) of PGH into pre-cleaned $5 \mathrm{~L}$ PET cans. Hospital wastewater samples were transported immediately after the collection to the laboratory, and were preserved at $4^{\circ} \mathrm{C}$. Then, the $\mathrm{pH}$, temperature, ORP, EC and DO, TSS and TDS of the sample were measured before analysis. Five different clay samples were selected from alluvial deposits considering color and texture. Clay samples were dried and powdered, and impurities were removed by the wet sieving using a $500 \mu \mathrm{m}$ sieve and distilled water. The separated clay was centrifuged and was transferred into beakers, and allowed to settle down. Then powdered clays were sieved again using $500 \mu \mathrm{m}$ sieve. The raw clay samples were analyzed using X-ray diffraction (XRD) pattern and it was identified that the samples mainly contain; montmorillonite, kaolinite, and illite clay compositions. 
Then, a weight of $10 \mathrm{~g}$ from each of the five raw clay samples was added into beakers separately with an equal volume $(100 \mathrm{ml})$ of $\mathrm{HWW}$, and kept for 2, 4, and 6 weeks in series. The duration to determine adsorption onto clay was; 2,4 , and 6 weeks and physical conditions were remaining similar for all the samples throughout the experiment. Then after two weeks of time, first series which consists of five clay samples were taken and each of the clay type was taken into the analysis.

Next, the filtrate was sucked out using a syringe without disturbing the clay surface, and the remaining clays were taken separately and were allowed to dry. Then, TSS and TDS were measured in filtrates. Fourier transform infrared spectroscopy (FTIR) analysis was done for the filtrate, determining the adsorption after 2, 4, and 6 weeks by filtering out $100 \mathrm{ml}$ of the sample from each clay type.

The same was done for the other two series of clay samples which were kept for four and six weeks of time periods. In order to compare with the treated samples, initial HWW samples were filtered out using $45 \mu \mathrm{m}$ filter paper. Then the suspended solids which was remained on filter paper, was dried and was analyzed using XRD and FTIR instruments. XRD analysis was carried out by Ultima IV X-ray diffractometer, and FTIR analysis is used to determine the bond nature of the sample. $\mathrm{KBr}$ method was used for the analysis by Bruker-Alpha spectrophotometer.

\section{RESULTS AND DISCUSSION}

Lack of investigations and information regarding HWW management (Kumarathilaka et al., 2015; Sorengard et al., 2019) and the high cost and the infrastructure requirements for waste management were identified as the reasons for not having proper waste disposal methods in Sri Lankan Hospitals. Still there are no specific guidelines, directions and defined standards that are followed to dispose of HWW in Sri Lanka (Haniffa, 2004; Chanpika et al., 2015; Kumarathilaka et al., 2015) excluding guideline introduced by World Health Organization
(WHO) which does not provide environmental polices (Chartier et al., 2014).

\section{The Water Analysis of the Hospitals and Performance of the Treatment Plant}

The Fig. 3a, 3b and 3c and Fig. 4a, 4b and 4c which are for two types of hospitals, illustrates the normalization with Sri Lankan CEA standards in order to show whether the analyzed chemical and physical parameters are below or above the Sri Lanka CEA standards.

The Fig. 5a-f, Fig. 6g-J show the physical and chemical parameters and Fig. 7 show the biological parameter change along with the treatment plant for the PGH which illustrates the performance of the existing treatment plant.

\section{Provincial General Hospital}

The Fig. $3 \mathrm{a}, 3 \mathrm{~b}$ and $3 \mathrm{c}$ shows the normalization with Sri Lankan CEA standards starting from before treatment plant (BTP), after settling tank (AST), after tickling filter (ATF), before Ultra Violet plant (BUVP) and After Ultra Violet plant (AUVP) for 3 days in PGH. Generally, in three days, it can be observed; $\mathrm{BOD}_{5}$ for BTP, AST, ATF and BUVP shows an increment because in the influent, a tremendous amount of organic materials is collected.

It is clear that TSS and phosphate have enriched for all locations in the treatment plant. The TDS shows slight increment in BTP, AST, ATF and BUVP as well. The temperature, DO, COD, Fe, $\mathrm{Mn}, \mathrm{Cd}$ and $\mathrm{Cu}$ levels show a depletion for all the locations. In last two days of the study in PGH (Fig. 3b and 3c), the effluent of the treatment (AUVP) plant also exceeds the CEA standard for the $\mathrm{BOD}_{5}$ level, even though the water was treated (Table 1). Organics provides medium for bacteriological activities by acting as a food source for water-borne bacteria which would lead to environmental impacts. It can be observed that COD of the water shows a little depletion due to the treatment processes (Fig. 3a, $3 \mathrm{~b}$ and $3 \mathrm{c})$. 

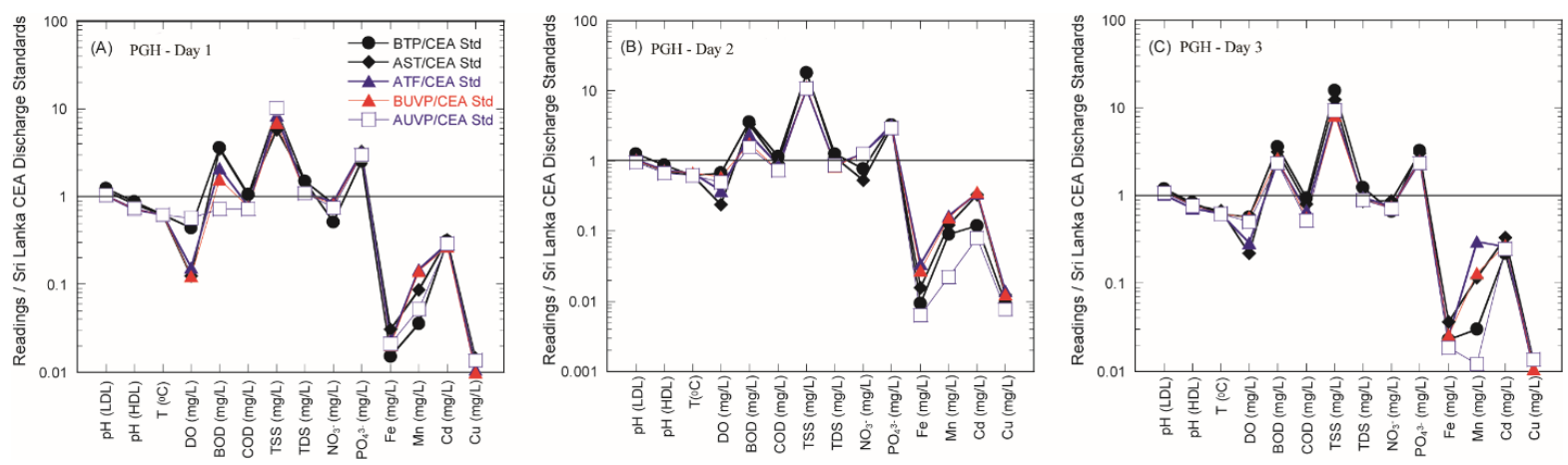

Fig. 3. Normalized water quality parameter variation in Provincial General Hospital in three days

Table 1. Water quality parameter variation in Provincial General Hospital in three days

\begin{tabular}{|c|c|c|c|c|c|c|c|c|c|c|c|c|c|c|c|}
\hline \multirow{2}{*}{ Parameter } & \multicolumn{3}{|c|}{ Before Treatment Plant (BTP) } & \multicolumn{3}{|c|}{ After Settling Tank (AST) } & \multicolumn{3}{|c|}{ After Trickling Filter (ATF) } & \multicolumn{3}{|c|}{ Before UV Treatment (BUVP) } & \multicolumn{3}{|c|}{ After UV Treatment (AUVP) } \\
\hline & Day 1 & Day 2 & Day 3 & Day 1 & Day 2 & Day 3 & Day 1 & Day 2 & Day 3 & Day 1 & Day 2 & Day 3 & Day 1 & Day 2 & Day 3 \\
\hline pH & 7.42 & 7.52 & 7.11 & 6.90 & 6.17 & 6.70 & 6.10 & 6.24 & 6.10 & 6.14 & 6.18 & 6.62 & 6.25 & 5.74 & 6.53 \\
\hline Temperature $\left({ }^{\circ} \mathrm{C}\right)$ & 25.0 & 25.0 & 25.0 & 25.0 & 25.0 & 27.1 & 25.0 & 27.2 & 25.0 & 25.0 & 27.2 & 25.0 & 25.0 & 25.0 & 25.0 \\
\hline ORP (mV) & -163 & -233 & -195 & -523 & -282 & -298 & -600 & -242 & -242 & -538 & -51 & -276 & -398 & -233 & -337 \\
\hline Conductivity $(\mu \mathrm{S} / \mathrm{m})$ & 50900 & 44200 & 48300 & 60100 & 47500 & 54100 & 41300 & 33400 & 56200 & 63300 & 32600 & 60500 & 63300 & 32700 & 38900 \\
\hline $\mathrm{DO}$ (mg/L) & 2.18 & 3.39 & 2.86 & 0.62 & 1.20 & 1.10 & 0.78 & 1.89 & 1.44 & 0.62 & 2.94 & 2.86 & 2.83 & 2.52 & 2.51 \\
\hline BOD (mg/L) & 108.30 & 106.80 & 108.60 & 104.10 & 101.40 & 94.20 & 63.00 & 72.30 & 72.90 & 47.40 & 53.10 & 79.50 & 21.90 & 46.80 & 69.90 \\
\hline $\operatorname{COD}(\mathrm{mg} / \mathrm{L})$ & 263.56 & 290.54 & 234.08 & 254.08 & 234.08 & 200.88 & 195.29 & 217.05 & 170.62 & 190.51 & 185.37 & 140.61 & 182.30 & 185.36 & 130.00 \\
\hline TSS (mg/L) & 480.00 & 904.00 & 781.00 & 290.00 & 896.00 & 615.00 & 420.00 & 524.00 & 450.00 & 350.00 & 560.00 & 410.00 & 510.00 & 536.00 & 470.00 \\
\hline TDS (mg/L) & 752.00 & 637.00 & 618.00 & 745.00 & 565.00 & 428.00 & 545.00 & 448.00 & 481.00 & 552.00 & 416.00 & 449.00 & 550.00 & 441.00 & 448.00 \\
\hline Total Solids (mg/L) & 762.00 & 1090.00 & 915.00 & 764.00 & 1120.00 & 941.00 & 752.00 & 920.00 & 756.00 & 788.00 & 890.00 & 782.00 & 772.00 & 950.00 & 810.00 \\
\hline $\mathrm{NO}_{3}^{-}(\mathrm{mg} / \mathrm{L})$ & 5.10 & 7.70 & 6.60 & 8.30 & 5.30 & 8.70 & 8.70 & 12.60 & 7.50 & 8.20 & 12.70 & 7.40 & 7.50 & 12.70 & 7.10 \\
\hline $\mathrm{PO}_{4}^{-3}(\mathrm{mg} / \mathrm{L})$ & 12.62 & 16.48 & 16.19 & 16.39 & 14.93 & 15.23 & 16.00 & 16.32 & 12.51 & 15.32 & 14.62 & 12.42 & 15.03 & 14.62 & 11.84 \\
\hline $\mathrm{Fe}(\mathrm{mg} / \mathrm{L})$ & 0.05 & 0.03 & 0.07 & 0.09 & 0.05 & 0.11 & 0.07 & 0.10 & 0.07 & 0.06 & 0.08 & 0.08 & 0.06 & 0.02 & 0.06 \\
\hline$M n(m g / L)$ & 0.02 & 0.05 & 0.02 & 0.04 & 0.06 & 0.06 & 0.07 & 0.08 & 0.15 & 0.07 & 0.08 & 0.07 & 0.03 & 0.01 & 0.01 \\
\hline $\mathrm{Cd}(\mathrm{mg} / \mathrm{L})$ & 0.03 & 0.01 & 0.02 & 0.03 & 0.03 & 0.03 & 0.03 & 0.04 & 0.03 & 0.03 & 0.04 & 0.03 & 0.03 & 0.01 & 0.03 \\
\hline $\mathrm{Cu}(\mathrm{mg} / \mathrm{L})$ & 0.04 & 0.03 & 0.04 & 0.04 & 0.04 & 0.04 & 0.03 & 0.04 & 0.03 & 0.03 & 0.04 & 0.03 & 0.04 & 0.02 & 0.04 \\
\hline
\end{tabular}

According to the chemical analysis for the three days (Fig. 3a, 3b and 3c), it shows that several water quality parameters of the treatment plant effluent is not within Sri Lankan CEA accepted levels and most of the times the effluent of the plant exceeds the Sri Lankan CEA accepted levels of $\mathrm{BOD}_{5}, \mathrm{PO}_{4}{ }^{3-}$, TSS (National Environmental (Protection and Quality Regulations, No.1 of 2008) and MTL of DO of 5 $\mathrm{mg} / \mathrm{L}$ (Begum and Harikrishna, 2008) which may badly affect the aquatic life (Fig. 3). Treatment plant collects water from various units of the hospital and it may include several kinds of nitrogen compounds and phosphorous compounds including several other organic compounds (Carraro et al., 2016). There are detergents which has phosphates that can be included as well (Emmanuel et al., 2005). In addition to that, results show that the composition of wastewater in the three days of the study was carried out, has fluctuating values indicating differences in the composition in each day (Fig. 3a, 3b and 3c). Thus, the water released each day differs in composition with the daily activities. $\mathrm{pH}$ values for Day 1 and 3 is within the CEA accepted range and Day 2 is not. The trace metals of $\mathrm{Fe}, \mathrm{Mn}, \mathrm{Cu}$ and $\mathrm{Cd}$ of the effluent have not exceeded standards within the days which the study was carried out (Fig. 3a, 3b and $3 \mathrm{c}$ ).

The chemical variation of $\mathrm{pH}, \mathrm{ORP}, \mathrm{EC}, \mathrm{DO}$, $\mathrm{BOD}_{5}$ and $\mathrm{COD}$ is given in Fig. 5 and TSS, TDS, $\mathrm{NO}_{3}{ }^{-}$and $\mathrm{PO}_{4}{ }^{3-}$ is given in Fig 6. According to the National Environmental Act, the accepted limit of $\mathrm{BOD}_{5}$ is $30 \mathrm{mg} / \mathrm{L}$. The average BOD value of the inlet water (before treatment plant - BTP) is $107.90 \mathrm{mg} / \mathrm{L}$ and at the end of the treatment process (AUVP) the average value is recorded as $46.20 \mathrm{mg} / \mathrm{L}$. The treatment plant is not able to remove BOD up to the accepted level although it treats water step 
by step to some extent (Fig. 5). The limit for COD is $250 \mathrm{mg} / \mathrm{L}$ according to the act and treatment plant removes COD from water up to the accepted level. In BTP, the COD is higher than $250 \mathrm{mg} / \mathrm{L}$ and then it decreases gradually (Fig. 5). Initially (BTP) it was averagely recorded as $262.73 \mathrm{mg} / \mathrm{L}$ which is higher than the discharge limit, but it decreases gradually to $165.89 \mathrm{mg} / \mathrm{L}$.

The accepted TSS standard value in the act is 50 $\mathrm{mg} / \mathrm{L}$ but it is not treated throughout the treatment process even at the end (AUVP). It was recorded as $505.33 \mathrm{mg} / \mathrm{L}$ average value which is very high comparing with the accepted limit. TSS value decreases after the settling tank (AST) and the trickling filter (ATF) but the average value again increases AUVP and exceeds the accepted limit (Fig. 6). The accepted limit for the phosphate is $5 \mathrm{mg} / \mathrm{L}$ and the average phosphate $\left(\mathrm{PO}_{4}{ }^{3-}\right)$ concentration of inlet (BTP) recorded as $15.10 \mathrm{mg} / \mathrm{L}$ which is very high. The outlet $\mathrm{PO}_{4}{ }^{3-}$ (AUVP) is recorded as $13.83 \mathrm{mg} / \mathrm{L}$ which is still higher than the allowable limit, indicating the treatment process has not effectively worked on treating phosphate (Fig. 6).

\section{Base Hospital - Type B}

It could be observed that BHTB had followed a procedure which did not consist of a treatment plant to maintain the waste management of the hospital. Here the solid waste is not mixed with water and the solid waste is disposed separately. The blackwater is collected into septic tanks and there is another underground tank to collect greywater from the kitchen of the hospital. Thus, those wastewaters are not mixing directly with natural water flows.

The water quality parameters for laboratory wastewater (CL) shows that, the amount of $\mathrm{BOD}_{5}$, TSS and DO is not in the accepted level (Fig. 4a, 4b and 4c) and it could be observed that this water was mixed with hazardous liquids such as infected body liquids (blood, urine, phlegm, etc.) and pharmaceuticals etc. Although the rate of wastewater generation is relatively low, these waters have been directed to the drainage system of the hospital. Therefore, there is a considerable possibility to mix this water with natural water bodies of the area.

According to the results, more quantity of greywater of the hospital is discharged by common water outlet (CWO). When the results are observed, it shows that generally, the amount of $\mathrm{BOD}_{5}, \mathrm{PO}_{4}{ }^{3-}$ and TSS of the water is not in the CEA accepted level (Fig. 4a, 4b and 4c). The $\mathrm{BOD}_{5}$ range of discharged water varies within the range of $81.25-94.50 \mathrm{mg} / \mathrm{L}$ (Table 2). The effluents from all the wards and wash water from the wash rooms and laundry is mixed in this outlet before discharge. The TSS content of water is high in all the sampling points excluding NK. The maximum level of $\mathrm{PO}_{4}{ }^{3-}$ is reported as $7.22 \mathrm{mg} / \mathrm{L}$ which are not within the CEA accepted range. Same as in PGH, results for BHTB shows higher levels mainly in $\mathrm{BOD}_{5}$, TSS and Phosphate (Fig. 4). CL and CWO are main outlets which discharge high amount of organic matters into the environment and higher growth of algae can be observed mainly in sampling sites.

It could be observed that the wash water from Tap near kitchen (NK) had not been contaminated frequently and the results of the study show that most of the parameters are in depleted range, comparing with the CEA standards (Fig. 4a, $4 b$ and $4 c$ ). The usage of the tap is also low, and it is used for small scale washing purposes, drinking and sometimes it is used by the kitchen workers. Therefore, the generation of the wastewater from this place is very low. However, sometimes the $\mathrm{PO}_{4}{ }^{3-}$ concentration of the water is exceeding the accepted level of $5 \mathrm{mg} / \mathrm{L}$ (Fig. 4a, $4 \mathrm{~b}$ and $4 \mathrm{c}$ ).

Both the hospitals of PHG and BHTB release water with higher levels of nutrients and common practice of BHTB is to deliver those waters directly to the environment. Therefore, the toxicity of water can be increased by high concentrations of nitrates and phosphates. Those nitrate compounds can easily be leached into the groundwater. Together nitrates and phosphates, contribute to eutrophication heavily and phosphate can be held by soil (Steinfeld et al., 2006). 

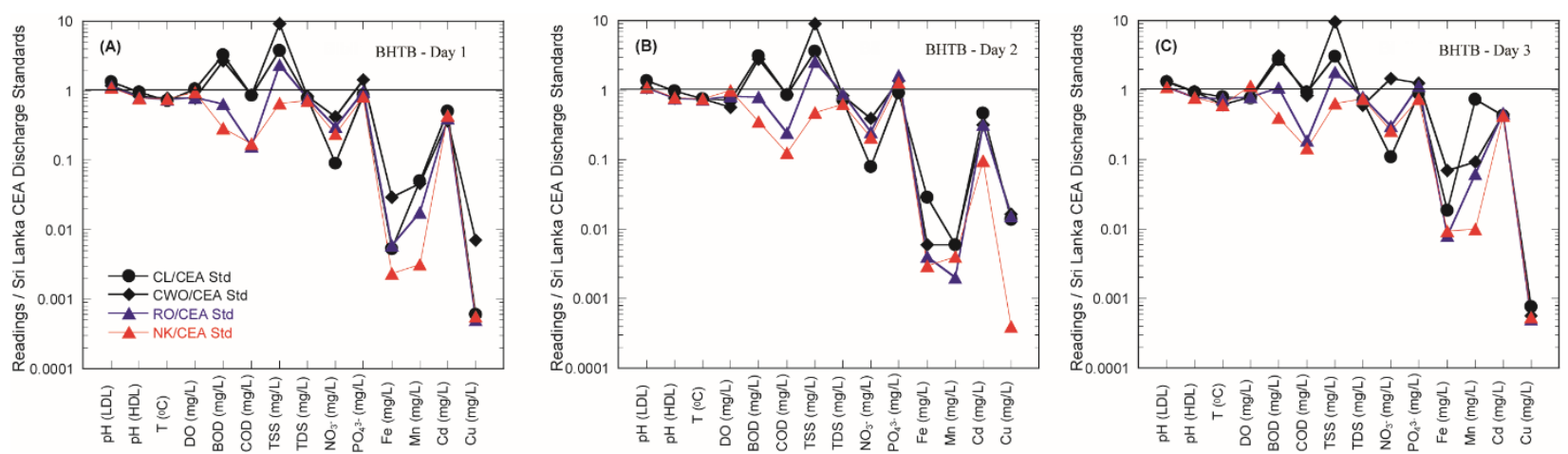

Fig.4. Normalized water quality parameter variation of wastewater outlets in Base Hospital Type B for three days

Table 2. Water quality parameters of Base Hospital - Type B in water outlets for three days

\begin{tabular}{|c|c|c|c|c|c|c|c|c|c|c|c|c|}
\hline \multirow{2}{*}{ Parameter } & \multicolumn{3}{|c|}{ Outlet of the Laboratory (CL) } & \multicolumn{3}{|c|}{ Common Water Outlet (CWO) } & \multicolumn{3}{|c|}{ Tap Near Kitchen (NK) } & \multicolumn{3}{|c|}{ RO Plant Effluent (RO) } \\
\hline & Day 1 & Day 2 & Day 3 & Day 1 & Day 2 & Day 3 & Day 1 & Day 2 & Day 3 & Day 1 & Day 2 & Day 3 \\
\hline pH & 8.13 & 8.30 & 7.85 & 7.07 & 6.48 & 8.09 & 6.63 & 6.62 & 6.60 & 6.87 & 6.57 & 6.72 \\
\hline Temperature $\left({ }^{\circ} \mathrm{C}\right)$ & 29.1 & 30.0 & 31.7 & 31.2 & 29.8 & 25.0 & 31.0 & 30.3 & 25.0 & 30.1 & 29.4 & 29.9 \\
\hline ORP (mV) & -238 & -239 & -242 & -163 & -177 & -188 & 163 & 176 & 189 & -243 & -238 & -229 \\
\hline Conductivity $(\mu \mathrm{S} / \mathrm{m})$ & 20300 & 35100 & 45600 & 49000 & 84900 & 39600 & 11470 & 27600 & 20000 & 30100 & 29400 & 29800 \\
\hline $\mathrm{DO}(\mathrm{mg} / \mathrm{L})$ & 5.36 & 3.60 & 3.85 & 3.93 & 2.83 & 4.03 & 4.80 & 5.02 & 5.76 & 3.97 & 4.11 & 3.99 \\
\hline $\mathrm{BOD}(\mathrm{mg} / \mathrm{L})$ & 98.25 & 93.75 & 81.90 & 81.25 & 83.75 & 94.50 & 8.71 & 10.50 & 12.00 & 19.50 & 24.00 & 32.60 \\
\hline $\operatorname{COD}(\mathrm{mg} / \mathrm{L})$ & 213.22 & 212.00 & 233.00 & 221.00 & 218.90 & 207.78 & 42.85 & 31.54 & 36.12 & 39.30 & 61.00 & 47.23 \\
\hline TSS (mg/L) & 189.00 & 182.00 & 152.00 & 461.00 & 456.00 & 480.00 & 33.00 & 24.00 & 32.00 & 117.00 & 129.00 & 92.00 \\
\hline TDS (mg/L) & 396.00 & 361.00 & 349.00 & 421.00 & 417.00 & 300.00 & 359.00 & 313.00 & 372.00 & 389.00 & 451.00 & 401.00 \\
\hline Total Solids (mg/L) & 503.00 & 489.00 & 410.00 & 815.00 & 816.00 & 730.00 & 372.00 & 310.00 & 360.00 & 481.00 & 515.00 & 470.00 \\
\hline $\mathrm{NO}_{3}^{-}(\mathrm{mg} / \mathrm{L})$ & 0.90 & 0.80 & 1.10 & 4.20 & 3.90 & 14.60 & 2.40 & 2.10 & 2.60 & 3.00 & 2.50 & 3.00 \\
\hline $\mathrm{PO}_{4}^{-3}(\mathrm{mg} / \mathrm{L})$ & 4.34 & 4.58 & 4.46 & 7.21 & 6.90 & 6.32 & 4.10 & 6.40 & 3.77 & 4.90 & 8.16 & 5.78 \\
\hline $\mathrm{Fe}(\mathrm{mg} / \mathrm{L})$ & 0.02 & 0.09 & 0.06 & 0.09 & 0.02 & 0.21 & 0.01 & 0.01 & 0.03 & 0.02 & 0.01 & 0.02 \\
\hline Mn (mg/L) & 0.03 & 0.00 & 0.37 & 0.02 & 0.00 & 0.05 & 0.00 & 0.00 & 0.01 & 0.01 & 0.00 & 0.03 \\
\hline $\mathrm{Cd}(\mathrm{mg} / \mathrm{L})$ & 0.05 & 0.05 & 0.04 & 0.04 & 0.03 & 0.05 & 0.04 & 0.01 & 0.04 & 0.04 & 0.03 & 0.05 \\
\hline $\mathrm{Cu}(\mathrm{mg} / \mathrm{L})$ & 0.00 & 0.04 & 0.00 & 0.02 & 0.05 & 0.00 & 0.00 & 0.00 & 0.00 & 0.00 & 0.05 & 0.00 \\
\hline
\end{tabular}

Although PGH and BHTB do not show higher levels of $\mathrm{Fe}, \mathrm{Mn}, \mathrm{Cd}$ and $\mathrm{Cu}$, these metals have an extreme hazardous nature because of their high solubility in the aquatic environments and because of that heavy metals can be consumed by living organisms. Once they enter the food chain, large concentrations of heavy metals may accumulate in the human body (Barakat, 2011). Therefore, though it is not a treat currently in the future measures should be taken to make sure that the metals do not exceed the standard levels. When the two hospitals of PGH and BHTB are compared. Clearly it can be observed that there are considerable differences of the composition of the wastewaters (Figs. 3 and 4). The reason for that is, types and the quantity of wastewater production of $\mathrm{PGH}$ is higher than BHTB because the number of patients, medical units and the waste production regarding with the patients is higher. However, it could be observed that high BOD, TSS, and Phosphate levels are common in both the hospitals which frequently exceed the CEA standards.

\section{Performance of Existing Treatment Plant of Provincial General Hospital}

According to the Figs. 5 and 6 it shows that in each sample point composition is fluctuating in the wastewater. When compare and consider the three days, it shows that characteristics and the composition of water is different in the three days. Water was collected from the common 
sump which is situated before the treatment plant (BTP).

The $\mathrm{pH}$ in the common sump (BTP) ranges between 7.11 - 7.52 which is neutral (Fig. 5a, Table 1). When water moves passing the settling tank, the $\mathrm{pH}$ show a clear drop (Fig. 5a, Table 1) and $\mathrm{pH}$ ranges between 6.17 - 6.90. Then, water moves through trickling filter and the $\mathrm{pH}$ value of water for Day 1 and 3 has decreased except Day 2. It ranges between $6.10-6.24$ which is slightly acidic. Thereafter, water retains at secondary settling tank and then flows through a drain which is open to the air. The $\mathrm{pH}$ value of water increases when water is mixing with air except on Day 2 (Fig. 5a). The ORP for Day 1 shows complete difference than Day 2 and 3 where Day 1 shows a decrease up to ATF and then increases up to AUVP (Fig. 5b). Day 2 and 3 shows somewhat similar pattern.
Day 3 fluctuates between (-)195 - (-)337mV which does not show much variation of the reducing environment compared to (-) $600 \mathrm{mV}$ in Day 1 and (-) $51 \mathrm{mV}$ in Day 2 maximum and minimum values respectively. This indicates that on Day 1 and Day 2 there may have been more organic matter content that has changed the reducing and oxidation conditions within the WWTP. Graphs show that a negative increase of ORP values when water has moved up to the settling tank, for all three days (Fig. 5b). Then, ORP increases (+ve) for Day 2 and Day 3 in ATF while it decreases (-ve) for Day 3. When water is discharged to the environment after the treatment, ORP value ranges between (-) 233 - () $398 \mathrm{mV}$.
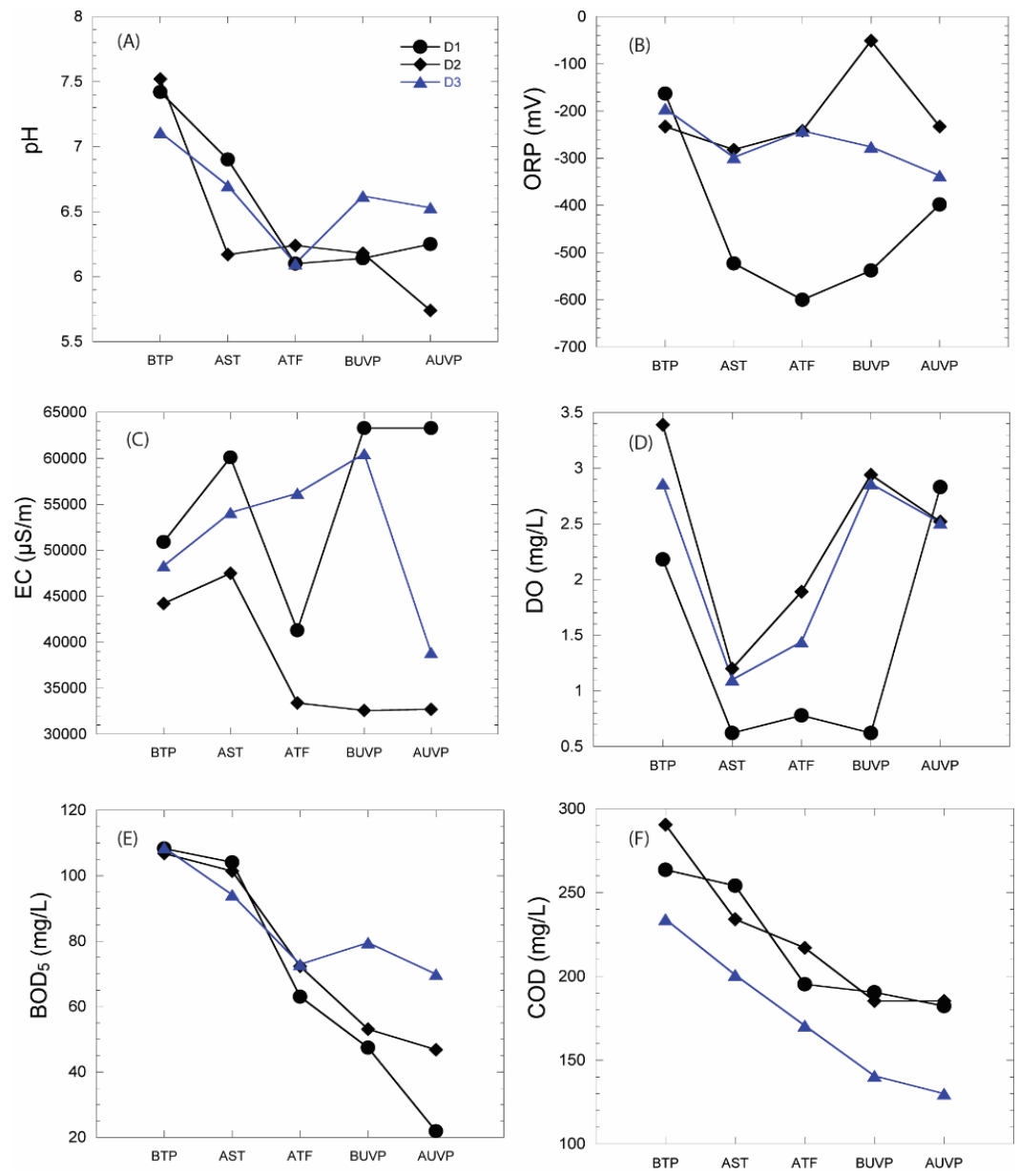

Fig.5. Water quality parameter variation throughout the treatment process 

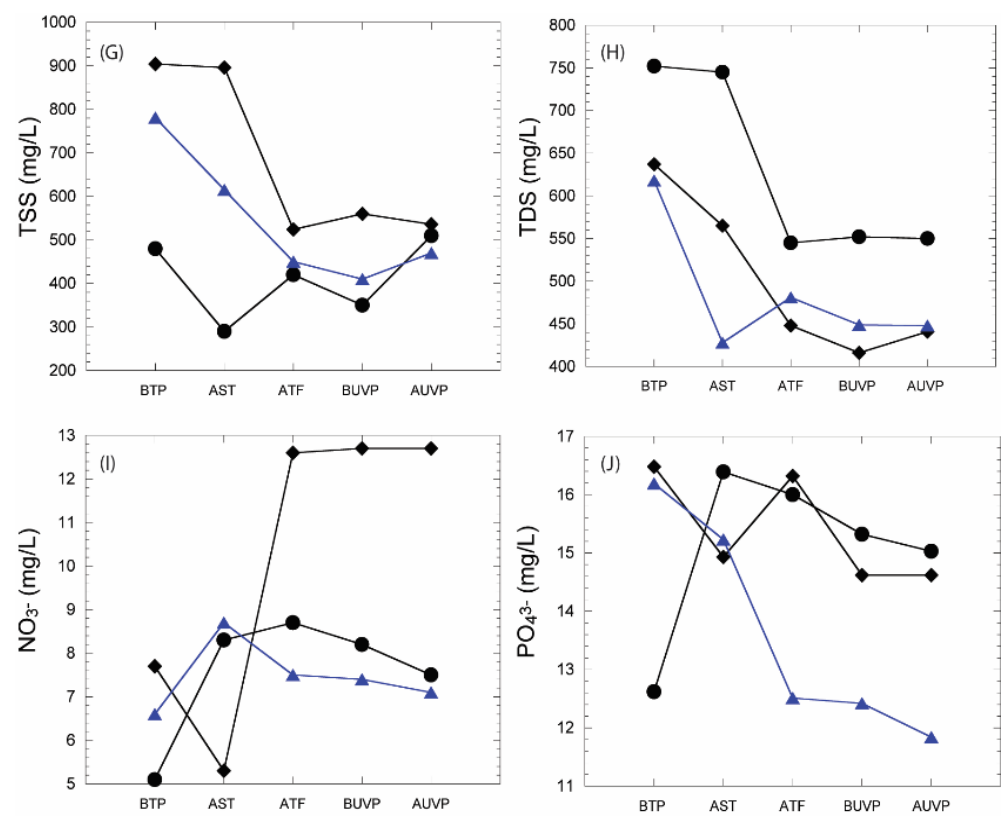

Fig.6. Water quality parameter variation throughout the treatment process

According to the values of DO, $\mathrm{pH}$ and the ORP values, it shows that characteristics of an anaerobic condition after moving through the settling tank. The acidity can damage wastewater facilities and disrupt the biological treatment processes (Amouei et al., 2015) and higher level of acidity of water can increase the toxicity of water by dissolving metals (Schindler et al., 1980). After moving through the trickling filter, water shows some aerobic characteristics comparing to the previous condition. While water mixes with air it increases the DO level and the ORP value of water (Fig. 5a, 5b and 5d). $\mathrm{pH}$ of water variates clearly towards acidic conditions with the decrease of DO of water. While water lowers the DO, it has started the fermentation process and acid forms. Water starts to mix with oxygen after the Trickling Filter and thereafter it was observed that the DO value has increased, and $\mathrm{pH}$ also increases while moving away from the acidic conditions. The variation of the average ORP also confirms the above argument. The variation of EC in the three days vary from each other except that up to AST all three days shows an increase (Fig. 5c). When the EC fluctuation of values of all three days is considered, it shows a high variation in all the days.
Common sump (BTP) consists of large quantity of organic materials and $\mathrm{BOD}_{5}$ ranges between $106.80 \mathrm{mg} / \mathrm{L}$ and $108.6 \mathrm{mg} / \mathrm{L}$, higher than the standards of $30 \mathrm{mg} / \mathrm{L}$ (Fig. 5e). The COD range of water was reported as $234-290 \mathrm{mg} / \mathrm{L}$ (Fig. 5f). Besides, it shows that $\mathrm{BOD}_{5}$ and $\mathrm{COD}$ levels of water have decreased after the settling tank (Fig. 5e and 5f). Initial $\mathrm{BOD}_{5}$ was reported as $106.8-108.6 \mathrm{mg} / \mathrm{L}$ and COD reported as $234.08-290.54 \mathrm{mg} / \mathrm{L}$. Although, it shows a drop of $\mathrm{BOD}_{5}$ and $\mathrm{COD}$ throughout the treatment but the $\mathrm{BOD}_{5}$ values of treated water ranged between $21.90-69.90 \mathrm{mg} / \mathrm{L}$, which exceed the standard values in Day 2 and Day 3 (Fig. 5e and 5f). The TSS of Day 1 differs while Day 2 and 3 are somewhat similar in variation (Fig. 6g). Water in the Common Sump (BTP) includes prominent level of TSS and it ranges between $480-904 \mathrm{mg} / \mathrm{L}$ which exceeds the standard level of $50 \mathrm{mg} / \mathrm{L}$ (Fig. $6 \mathrm{~g}$ ). After water moved through the settling tank (AST) and there after the TSS shows a clear drop. TSS values in wastewater was dropped after the trickling filter. However, it was reported that the TSS range of treated water ranged between $470-510 \mathrm{mg} / \mathrm{L}$ which is not meet the CEA standard $(50 \mathrm{mg} / \mathrm{L})$. It is observed that in the treatment plant, there is substantial amounts of algae. In the effluent released to the environment, there was considerable number of algae which was 
reflected by the TSS. According to the results, it shows a clear drop of $\mathrm{BOD}_{5}$ and TSS after the trickling filter except in TSS level

of Day 1 (Fig. 5e and 6g). Average removal of COD, BOD5 and TSS is $15 \%, 31 \%$ and $23 \%$ respectively after the trickling filter. At the end of the treatment process there are considerable amounts of dead algae produced. Therefore, effluent has high level of TSS. It shows that the efficiency of the trickling filter is not in optimum level. TDS is naturally present in the water but higher concentrations of such effluent, changes to the ionic balance of the water. Also, TDS cause toxicity through increases in salinity, changes in the ionic composition of the water and toxicity of individual ions (Scannell and Duffy, 2007). The values for $\mathrm{PO}_{4}{ }^{3-}$ at BTP shows very high values and it shows a decrease after the settling tank except in Day 1 (Fig. 6J). Throughout the treatment process, $\mathrm{PO}_{4}{ }^{3-}$ of water shows a clear decrease in Day 2 and 3. However, the $\mathrm{PO}_{4}{ }^{3-}$ range of the treated water was reported as $11.84-15.03 \mathrm{mg} / \mathrm{L}$ which does not meet the CEA standard.

Results shows that the filter reduces some amount of nitrate, phosphate and metals in within a highly fluctuating composition. The reason for increasing Nitrate is reactions of nitrifying bacteria (Steinfeld et al., 2006). They change nitrate concentration according to the condition. Some amount of nutrients is taken up by the microorganisms in the bio films. Water is already mixed with higher amount of nutrient content and after the settling tank and trickling filter, it shows nitrifying bacteria has started to react and produce $\mathrm{NO}_{3}{ }^{-}$(Fig. $6 \mathrm{i}$ and $6 \mathrm{j}$ ).

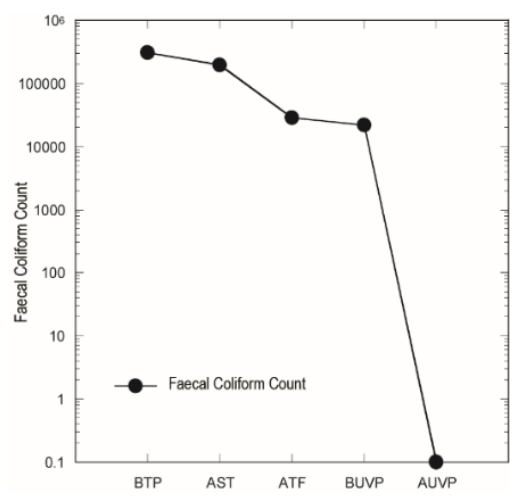

Fig.7. Drop of the Faecal Coliform throughout the treatment process
According to the graphs it shows a gradual decease in values for TSS, $\mathrm{BOD}_{5}, \mathrm{COD}$ and $\mathrm{PO}_{4}{ }^{3-}$ but a drastic decrease cannot be observed (Figs. 5 and 6). When other parameters are considered, it shows a high fluctuating nature in the composition throughout the treatment process within the three days (Figs. 5 and 6).

When water moves through the treatment plant, Fig. 7 shows a clear reduction of faecal coliform of the water. In the sample point before entering the treatment plant, it shows the number of faecal coliform is around $3 \times 10^{5} \mathrm{MPN} / 100 \mathrm{ml}$. Then after the settling tank, nearly $36 \%$ of the initial number of faecal coliform is reduced into $1.93 \times 10^{5} \mathrm{MPN} / 100 \mathrm{ml}$. After the trickling filter, it shows that clear drop of the number of faecal coliform. It reduced the number by around $88 \%$ of the water after the settling tank. The number has been reported as $2.8 \times 10^{4}$ MPN/100 $\mathrm{ml}$. Then before the UV treatment the value is $2.1 \times 10^{4} \mathrm{MPN} / 100 \mathrm{ml}$ and after all the treatments it shows zero faecal coliform detection.

Variation of faecal coliform shows a reduction in the treatment steps and it is reduced up to zero coliform detection because of the influence of UV light and the chemical disinfection process of chlorine (Fig. 7). Chlorine is a strong oxidizer and it has very strong sterilizing ability (Chen et al., 2014). Combined inactivation of UV and Chlorine is very high, and chlorine has more efficiency (Montemayor et al., 2008).

According to the results, it shows that the treatment plant is in operation and it removes contaminants up to some extent, but it is not sufficient to meet the CEA standards.

\section{The Clay Analysis of the Wastewater to Remove TSS and TDS}

For the water analysis, the HWW samples were collected and analyzed initially. After identification of the HWW is consisted of high TSS $(505 \mathrm{mg} / \mathrm{L})$ and TDS (479 $\mathrm{mg} / \mathrm{L})$ the water samples were re-collected and analyzed for TSS and TDS. Then, the TSS value of HWW sample was obtained as $1534 \mathrm{mg} \mathrm{L}^{-1}$.

The XRD analysis for the raw clay samples showed that the clays were composed of illite, 
kaolinite and montmorillonite (Fig. 8). In the illite clay containing water the TSS levels were reduced from $1534 \mathrm{mg} / \mathrm{L}$ to $61 \mathrm{mg} / \mathrm{L}$ which was achieved within 2 weeks where $96.02 \%$ of TSS was removed by the illite clay (Fig. 9a). Highest removal of TDS was achieved by illite clay within 2 weeks and the removal percentage of TDS was $43.27 \%$ (Fig. 9b). Further, the XRD analysis has shown that several chemical components have been adsorbed by clay which are found to be in HWW.

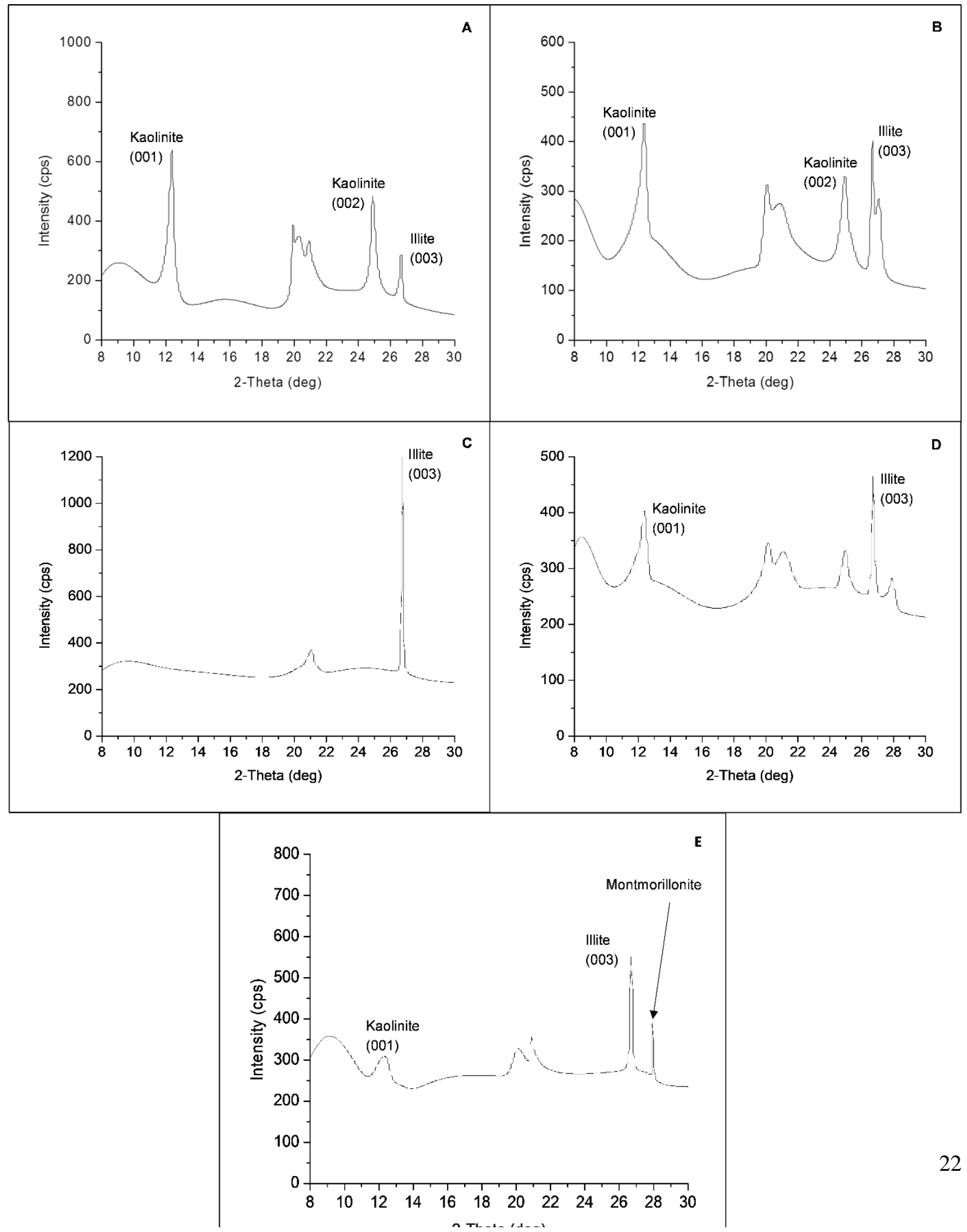

Fig.8. The XRD analysis that shows the clays used Illite, Kaolinite and Montmorillonite 


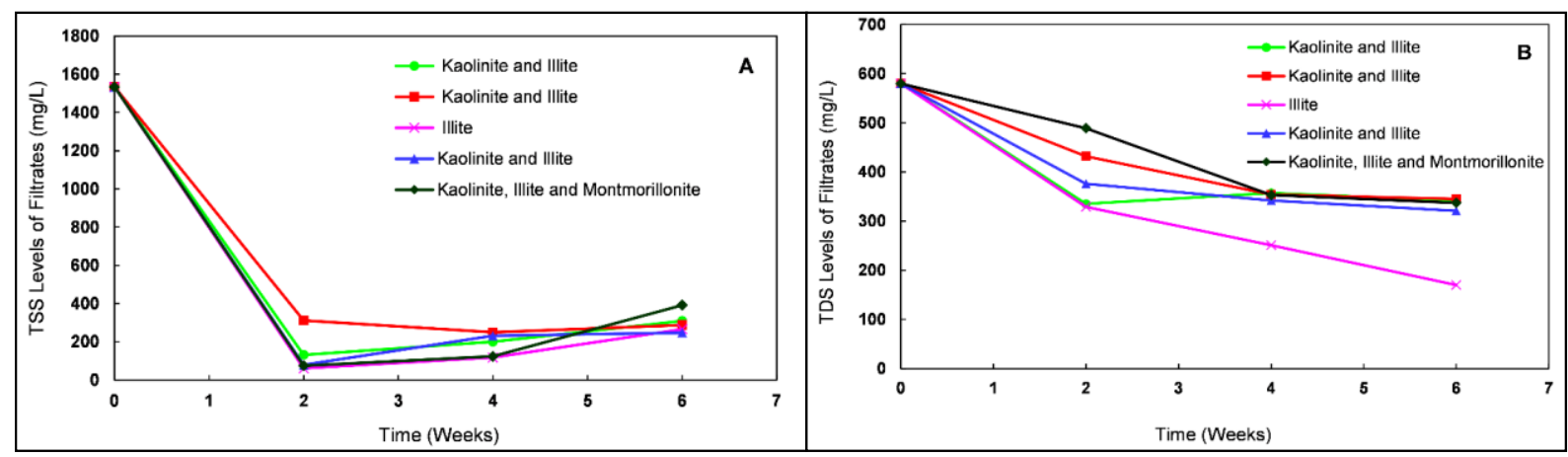

Fig.9. Removal percentage of a) TSS and b) TDS into Illite clay with duration

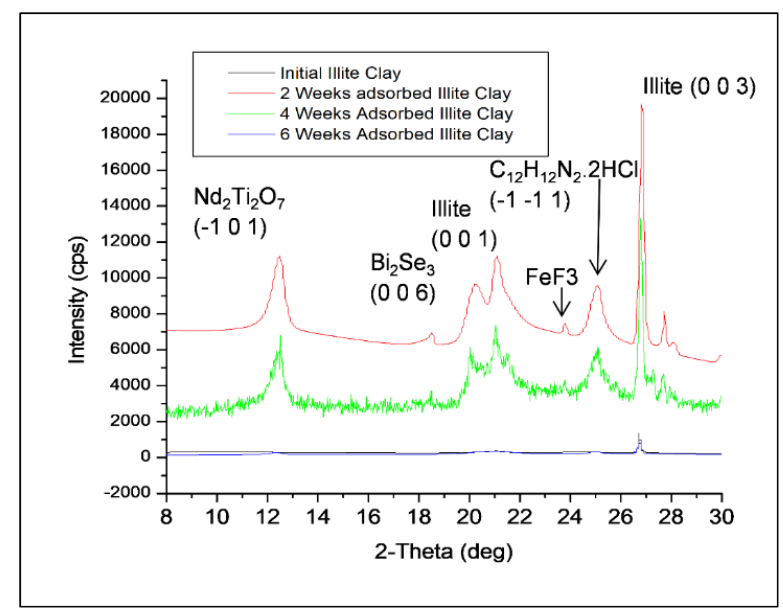

Fig. 10. XRD graphs of initial and adsorbed Illite clay within 2 weeks, 4 weeks and 6 weeks

The XRD analysis shows that, Benzidine dihydro-chloride $\left(\mathrm{C}_{12} \mathrm{H}_{12} \mathrm{~N}_{2} .2 \mathrm{HCl}\right)$, Neodymium titanium oxide $\left(\mathrm{Nd}_{2} \mathrm{Ti}_{2} \mathrm{O}_{7}\right)$, Ferric fluoride $\left(\mathrm{FeF}_{3}\right)$ and Bismuth selenide $\left(\mathrm{Bi}_{2} \mathrm{Se}_{3}\right)$ have been adsorbed within 2 weeks into illite clay. Further, Neodymium titanium oxide and Benzidine dihydrochloride have been adsorbed within 4 weeks. It was also evidenced that Ferric fluoride and Bismuth selenide which are found to be hospital waste have been desorbed after 4 weeks. Benzidine dihydrochloride and Neodymium titanium oxide have been adsorbed after 6 weeks (Fig.10).

Major functional groups contained in hospital wastewater identified were $\mathrm{O}-\mathrm{H}, \mathrm{CH}_{3}$, Amino acid, $\mathrm{C}=\mathrm{O}, \mathrm{COO}^{-}, \mathrm{CH}_{2} \mathrm{OH}$ and $\mathrm{C}-\mathrm{Br}$ (Fig. 11).

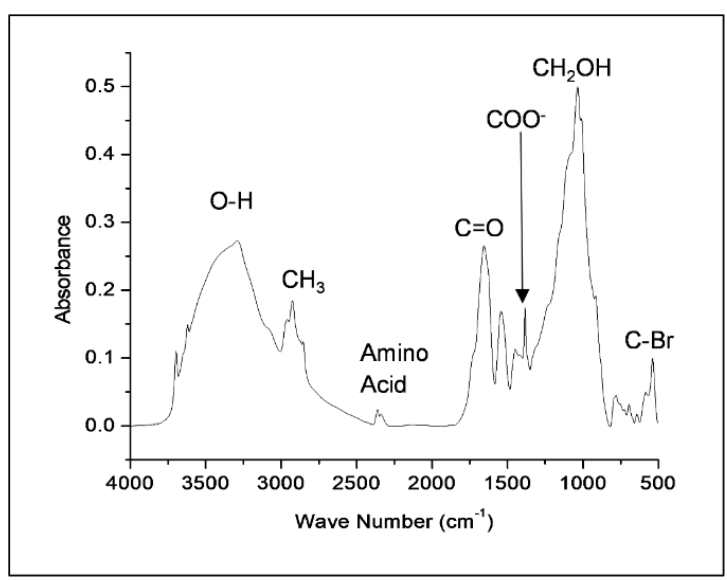

Fig.11. FTIR graph for suspended solids contained in Hospital Wastewater

Almost all the functional groups are organic functional groups.

The scanning electron microscope (SEM) images show the adsorption after two weeks in illite (Fig. 12).

\section{CONCLUSION}

Wastewater generation is continuing to rise due to the increase in the number of patients and the medical treatment facilities in the PGH and the BHTB. The study confirms that the existing treatment facility at $\mathrm{PGH}$ should be improved as it was not able to meet CEA standards, especially for TSS, TDS, $\mathrm{PO}_{4}{ }^{3-}$ and $\mathrm{NO}_{3}{ }^{-}$. Thus, there is a vital necessity for improvements in the existing treatment plant in PGH according to the 

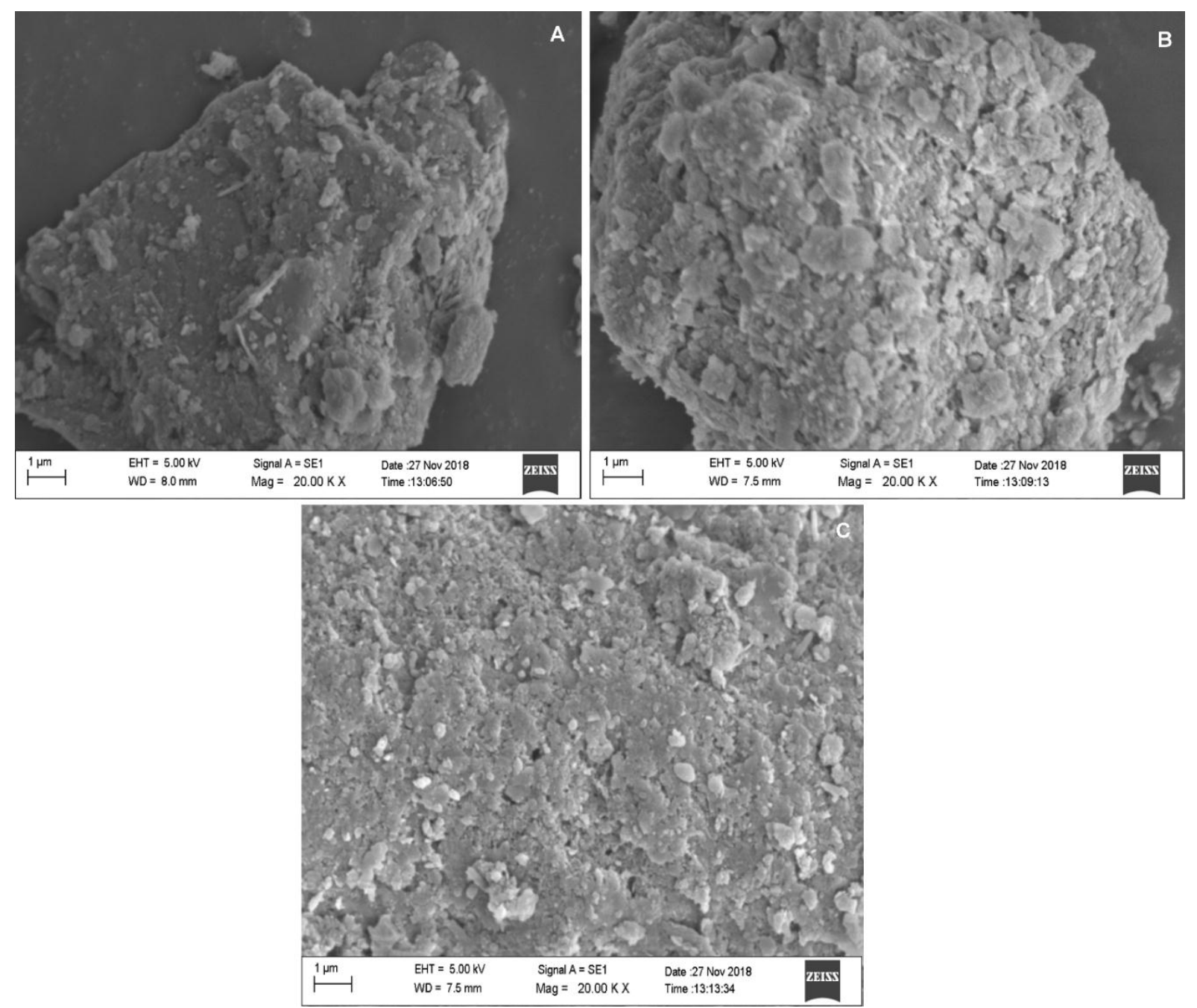

Fig.12. a) Untreated Illite, b) Treated after two weeks c) Treated after six weeks

extent of contaminants and increase of wastewater generation. It is required to build in a wastewater treatment facility in BHTB as the wastewaters show considerable environmental contamination possibilities. It is required to develop standardized environmental guidelines for HWW treatment in all types of hospitals as the attention for HWW is of very much important regardless the hospital type.

Study was extended to determine the effectivity of clay as a filter material to remove TSS and TDS which was found high in HWW. The treatment of HWW using clay showed that, illite clay can be used successfully as an adsorbing agent to remove TSS and TDS in HWW. As per the results, the optimum clay to adsorb and to remove the TSS and TDS in HWW was found to be the clay sample which was with illite as the major constituent. Removal percentages of TSS and TDS for illite clay were $96.02 \%$ and $43.27 \%$ respectively which were reached within two weeks. Further, it shows that illite clay also adsorbs Benzidine dihydrochloride $\left(\mathrm{C}_{12} \mathrm{H}_{12} \mathrm{~N}_{2} .2 \mathrm{HCl}\right)$, Neodymium titanium oxide $\left(\mathrm{Nd}_{2} \mathrm{Ti}_{2} \mathrm{O}_{7}\right)$, Bismuth selenide $\left(\mathrm{Bi}_{2} \mathrm{Se}_{3}\right)$ and Iron fluoride $\left(\mathrm{FeF}_{3}\right)$ which are found to be in HWW. 


\section{REFERENCE}

American Public Health Association. (1998) Standard methods for the examination of water and wastewater: Washington. DC, American Public Health Association, American Water Works Association, and Water Environment Federation, 3-37.

Amouei, A., Asgharnia, H., Fallah, H. and Faraji, H. (2015) Characteristics of effluent wastewater in hospitals of Babol University of Medical Sciences, Babol Iran. Journal of Health Scope, 4(2): 4-7.

Aththanyaka, W. K. A. M. T. S., Asanthi, H. B. and Maithreepala, R. A. (2014) An assessment of the effects of hospital wastes released to Nilwala river, Matara. Journal of the University of Ruhuna, 2: 33-39.

Barakat, M. A. (2011) New trends in removing heavy metals from industrial wastewater. Arabian Journal of Chemistry, 4(4): 361-377.

Begum, A., and Harikrishnarai (2008) Study on the quality of water in some streams of Cauvery River. E-Journal of Chemistry, 5(2): 377-384.

Cadena, F., Rizvi, R. and Peters, R.W., (1990) Feasibility studies for the removal of heavy metals from solution using tailored bentonite. In Hazardous and Industrial WastesProceedings of the Mid-Atlantic Industrial Waste Conference pp. 77-94.

Carraro, E., Bonetta, S., Bertino, C., Lorenzi, E., Bonetta, S. and Gilli, G. (2016) Hospital effluents management: chemical, physical, microbiological risks and legislation in different countries.

Chanpika, L. B., Priyantha, A. P. and Masafumi, T. (2015) Recommendations through a complete study on healthcare solid waste management practices of government hospitals in Colombo, Sri Lanka. International Journal of Waste Resources, 5: 178.

Chartier, Y., Emmanuel, J., Pieper, U., Prüss, A., Rushbrook, P., Stringer, R., Townend, W., et al. (2014) Safe management of wastes from health-care activities. Geneva: World Health Organizatiion.

Chen, L., Zhou, H., Yu, B. and Huang, Z. (2014) Comparison Study on Hospital Wastewater Disinfection Technology. Journal of
Advanced Materials Research, 884: 41-45.

Emmanuel, E., Perrodin, Y. and Vermande, P. (2002) Effects of hospital wastewater on aquatic ecosystem, In Proceedings of the XXVIII Congreso Interamericano de Ingenieria Sanitaria y Ambiental. Cancun, México PP. 27-31.

Emmanuel, E., Perrodin, Y. Keck, G. Vermande, P. and Blanchard, J. M. (2005) Ecotoxicological risk assessment of hospital wastewater: a proposed framework for raw effluents discharging into urban sewer network. Journal of Hazardous Materials, 117(1): 1-11.

Frederic, O. and Yves, P. (2014) Pharmaceuticals in hospital wastewater: Their ecotoxicity and contribution to the environmental hazard of the effluent. Chemosphere, 115: 31-39

Haniffa, R. (2004). Management of health care waste in Sri Lanka. Ceylon Medical Journal, 49(3): 93-95.

Hascakir, Berna \& Dolgen, Deniz. (2008). Utilization of Clay Minerals in Wastewater Treatment: Organic Matter Removal with Kaolinite. 17: 47-54.

Jean, J., Perrodin, Y., Pivot, C., Trepo, D., Perraud, M., Droguet, J., et al. (2012) Identification and prioritization of bioaccumulable pharmaceutical substances discharged in hospital effluents. Journal of Environmental Management, 103: 113-121.

Jiang, Jia-Qian \& Zeng, Zhiqiang \& Pearce, Peter. (2004) Preparation and Use of Modified Clay Coagulants for Wastewater Treatment. Water Air and Soil Pollution. 158. 53-65.

Jones, O. A. H., Voulvoulis, N. and Lester, J. N. (2005) Human Pharmaceuticals in Wastewater Treatment Processes. Critical Reviews in Environmental Science and Technology, 35(4): 401-427 Journal of Environmental Management, 168: 185-199

Kumarathilaka, P., Jayawardhana, Y., Dissanayaka, W. and Herath, I. (2015) General Characteristics of Hospital Wastewater from Three Different Hospitals in Sri Lanka. Paper presented at the 6th International Conference on Structural Engineering and Construction Management 2015, Kandy, Sri Lanka, 11-13 
Mahmoudkhani, R., Azar, A. M. and Khani, M. R. (2012) A survey of Tehran hospital wastewater. 2012 International Conference on Future Environment and Energy, 28: 5660

Meo, M. I., Haydar, S., Nadeem, O., Hussain, G. and Rashid, H. (2014) Characterization of hospital wastewater, risk waste generation and management practices in Lahore, Proceedings of the Pakistan Academy of Sciences, Pakistan Academy of Sciences, 51 (4): 317-329.

Montemayor, M., Costan, A., Lucena, F., Jofre, J., Munoz, J., Dalmau, et al. (2008) The combined performance of UV light and chlorine during reclaimed water disinfection. Water Science and Technology, 57(6): 935940.

National Environmental (Protection and Quality) Regulations, No.47 of 1980, No.1 of (1A), 31A, Ministry of Environment and Natural Resources, Sri Lanka, 2008.

Nemathaga, F., Maringa, S. and Chimuka, L. (2008) Hospital solid waste management practices in Limpopo Province, South Africa: A case study of two hospitals. Waste Management, 28(7): 1236-1245

Pandey, S. and Dwivendi, A. K. (2016) Nosocomial Infections through Hospital Waste. International Journal of Waste Resources, 6(1)

Paulus, G. K., Hornstra, L. M., Alygizakis, N., Slobodnik, J., Thomaidis, N., \& Medema, G. (2019) The impact of on-site hospital wastewater treatment on the downstream communal wastewater system in terms of antibiotics and antibiotic resistance genes. International journal of hygiene and environmental health, 222(4): 635-644.

Pescod, M.B. (1992) Wastewater treatment and use in agriculture. Rome: FAO

Prayitno, Kusuma, Z., Yanuwiadi, B. and Laksmono, R.W. (2013) Study of hospital wastewater characteristic in Malang City. International Journal Of Engineering and Science, 2(2): 13-16.

Scannell, P. K. W. and Duffy, L. K. (2007) Effects of total dissolved solids on aquatic organisms: A review of literature and recommendation for Salmonid species.
American Journal of Environmental Sciences, 3(1): 1-6.

Schindler, D. W, Hesslein, R. H., Wagemann, R. and Broecker, W. S. (1980). Effects of acidification on mobilization of heavy metals and radionuclides from the sediments of a freshwater lake. Canadian Journal of Fisheries and Aquatic Sciences, 37(3): 373377.

Sorengard, M., Campos-Pereira, H., Ullberg, M., Lai, F. Y., Golovko, O., \& Ahrens, L. (2019). Mass loads, source apportionment, and risk estimation of organic micropollutants from hospital and municipal wastewater in recipient catchments. Chemosphere, 234, 931-941.

Srinivasan, R. (2011) Advances in application of natural clay and its composites in removal of biological, organic, and inorganic contaminants from drinking water. Advances in Materials Science and Engineering.

Steinfeld, H., Gerber, P., Wassenaar, T. D., Castel, V. and De Haan, C. (2006) Livestock's long shadow: environmental issues and options. FAO

Tilley, E., Lüthi, C., Morel, A., Zurbrügg, C. and Schertenleib, R. (2014) Compendium of Sanitation Systems and Technologies (2nd Revise). Dübendorf, Switzerland: Swiss Federal Institute of Aquatic Science and Technology.

Todt, D. (2015) Source separating sanitary systems energy efficient treatment of blackwater and minimizing greenhouse gas emissions, Philosophiae Doctor (PhD) Thesis. Department of Environmental Sciences, Norwegian University of Life Sciences.

Wiest, L., Chonova, T., Bergé, A., Baudot, R., Barbier, F.B., Ayouni-Derouiche L., et al. (2018) Two-year survey of specific hospital wastewater treatment and its impact on pharmaceutical discharges. Environmental Science and Pollution Research, 25(10): 9207-9218.

Zenker, A., Cicero, M. R., Prestinaci, F., Bottoni, P. and Carere, M. (2014) Bioaccumulation and biomagnification potential of pharmaceuticals with a focus to the aquatic environment. Journal of Environmental Management, 133: 378-387. 
